\title{
BIOELECTRICITY PRODUCTION FROM CASSAVA MILL EFFLUENTS USING MICROBIAL FUEL CELL TECHNOLOGY
}

\author{
S. E. Agarry ${ }^{1,}{ }^{*}$, K. M. Oghenejoboh ${ }^{2}$ and B. O. Solomon ${ }^{3}$ \\ 1,2Department of Chemical Engineering, Delta State University, Oleh Campus. Delta State. Nigeria.

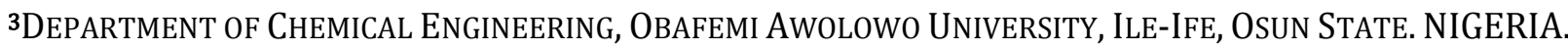 \\ E-mail addresses. ${ }^{1}$ sam_agarry@yahoo.com, ${ }^{2}$ kmoghene@yahoo.com, ${ }^{3}$ bos77consult@yahoo.com
}

\begin{abstract}
A Microbial Fuel Cell (MFC) is a biochemical-catalyzed system that generates electricity by oxidation of biodegradable organic substance in the presence of microorganisms or enzymes. Microbial fuel cell technology is a new form of renewable and sustainable technology for electricity generation as it recovers energy from renewable materials such as organic wastes and wastewaters that can constitute environmental pollution if not disposed without proper treatment. This work therefore investigated the possibility of electricity generation from cassava mill effluent using MFC. The cassava mill effluent was found to generate voltage and current to the maximum of 275 $\mathrm{mV}$ and $2.75 \mathrm{~mA}$, respectively, corresponding to a maximum power density of $189 \mathrm{~mW} / \mathrm{m}^{2}$. The voltage and current generation was respectively and significantly influenced with change in temperature, $p H$, concentration (strength) of effluent and addition of nutrient. Thus, it can be concluded that bioelectricity can directly be generated from cassava mill effluent using the MFC technology
\end{abstract}

Keywords: Bioelectricity; Cassava mill effluent; Microbial Fuel Cell; Power density.

\section{INTRODUCTION}

Increasing human activities is leading to increasing consumption of the natural non-renewable sources of energy and subsequently resulting to faster rate of fossil fuels depletion. Therefore, energy derived from fossil fuels may not be able to solve the energy crisis as the source gets depleted and generates environmental pollution due to the release of greenhouse gases that results in climate change and global warming [1]. The present-day energy (electricity) scenario in Nigeria and around the world is precarious, thus driving to the search of alternative to fossil fuels. The current energy production methods are not sustainable, and concerns about climate change and global warming require developing new technologies of energy production using renewable and carbon-neutral sources [2]. Electricity is one of the most important types of energy needed for day to day life. The production of electricity by nuclear fuel is radioactive and harmful for the environment. Also, electricity generation by chemicals is too expensive and they are very harmful for the environment. To overcome these entire problems, technology that focused on biological resources to generate electricity without affecting the environment and at low cost is required [3].

A technology using microbial fuel cells (MFCs) that convert the energy stored in chemical bonds in organic compounds to electrical energy (bioelectricity) achieved through the catalytic reactions by microorganisms has been developed and has generated considerable interests among academic researchers in recent years $[4,5]$. The concept of electricity production from bacteria (bioelectricity) was conceived nearly a century ago by Potter [6], however, only recently the technology has been sufficiently improved to make it useful as a method for energy generation. Bioelectricity is an electric current that is generated by a variety of biological processes and generally range from one to few hundred millivolts [7]. A microbial fuel cell (MFC) has the potential to generate bioelectricity directly from a fermentative substrate and gains prominence due to its clean, efficient, and renewable nature [8,9].

MFC is a hybrid bio-electrochemical system that directly transforms chemical energy to electrical 
energy via electrochemical reactions involved in biochemical pathways. Microorganisms serve as biocatalysts and convert the energy stored in chemical bonds of bio-convertible substrates into electricity under ambient pressures and temperatures $[2,10]$. MFCs consist of two chambers, an anaerobic anode chamber and an aerated cathode chamber, which are separated by proton exchange membrane or salt bridge. In the anode compartment of MFC, microorganisms oxidize organic substrate such as acetate [11], glucose [12], sucrose [13], an amino acid (cysteine) [14], a protein (bovine serum albumin) [15], wastewater or any other sugary and hydrogenated compound as fuel thus generating free electrons and protons (hydrogen ions). The protons generated passes through the proton exchange membrane (such as Nafion) or salt bridge to the cathode chamber [16] filled with aerated water and the free electrons are transferred through the external circuit connected to a volt meter to the cathode. At the cathode chamber, the electrons combine with protons in the presence of oxygen (an electron acceptor) to form water [17]. Oxygen is superior to other electron acceptors for its unlimited availability and its high redox potential [18]. Commonly, oxygen as a terminal electron acceptor is added to the cathode. Consumption of electrons and protons is terminated by oxygen; water molecules are formed, then the transfer cycle reached at the end. Oxidized mediators can also accelerate reaction of water formation in the cathode chamber. Oxygen in the anode chamber may inhibit production of electricity, so the system must be designed in such a way as to keep the bacteria separated from the oxygen (anaerobic chamber for anodic reaction) [19].

Bacteria present in mediator less MFCs have electrochemically active redox enzymes on their outer membranes that transfer the electrons to external materials and therefore, do not require exogenous chemicals to accomplish electron transfer to the electrode [20]. Nevertheless, most of the bacteria species used are inactive for electron transport; hence, most MFCs use or require mediator molecules (synthetic or natural) such as methylene blue (MB), neutral red (NR), thionin, ferricyanide, humic acid, or methyl viologen [21] to be artificially added to the anode chamber as to speed up electron transportation to the electrode surface [22]. The presence of artificial electron mediators is essential in some of MFCs so as to improve its performance [23]. But recently, mediator less MFCs became an interesting issue for many researchers [8] because the addition of mediators in the commercial use of MFCs for energy production and wastewater treatment faces trouble, as most of these mediators are expensive and toxic $[24,25]$. Therefore, there is a lot of emphasis for improving MFCs without the use of mediators..

MFCs have many advantages, including the cleanliness of the process, efficiency, easy conduct in different circumstances and not producing toxic side byproducts; and therefore have shown to be a better option for producing electricity and simultaneous treatment of wastewater while producing clean, simple and complete renewable energy [26, 27]. Waste water sources that have been used in MFC tests include domestic wastewater [26], swine wastewater [28], meat packing wastewater [15], paper industry wastewater [2], corn stover hydrolysates (liquefied corn stover) [29] and abattoir waste water, dairy waste water, sugar mill waste water, brewery waste water and pineapple juice waste water [7]. Thus, the high organic load in wastewaters is no longer seen as waste, but instead as a valuable energy resource. The function of microbial fuel cells is affected by several factors such as the amount of oxidation and electron transfer to the electrodes by microorganisms, loading rate, the nature of the used carbon source, the nature of the proton exchange membrane, proton transfer through the membrane to the cathode chamber, oxygen supply in the cathode, the nature and type of electrodes, circuit resistance, the electrolyte used, operation temperature, $\mathrm{pH}$, sedentary time, microorganism, and nutrients[30, 31, 32]. Ways of exploiting these biological substrates degradation for the generation of electricity is the driving force for the development of microbial fuel cell (MFC).

The objective of this work was to investigate the potential of bioelectricity production from cassava mill effluent which are rich in organic substrates as well as microorganisms using mediator less Microbial Fuel Cell. Also, the effect of initial concentration, $\mathrm{pH}$, temperature and the addition of NPK fertilizer as nutrient on voltage and current generation was investigated.

\section{MATERIALS AND METHODS}

\subsection{Materials}

The cassava mill effluent used in this work was collected from a cassava processing factory located in Obiaruku of latitude $15^{\circ} \mathrm{C} 51^{\prime \prime}$ North and longitude $61^{\circ} \mathrm{C} 09^{\prime \prime}$ East of Delta State, Nigeria. 


\subsection{Methods}

\subsubsection{Physical and chemical characterization of wastewater sample}

The cassava mill effluent was characterized for their physical and chemical properties according to APHA standard methods [33] and their microbial constituents isolated. The physical and chemical characterization of cassava liquid waste effluents is presented in Table 1.

\section{Table 1. Characterization of cassava mill effluent}

\begin{tabular}{ll}
\hline Parameters & Value \\
\hline $\mathrm{pH}$ & 4 \\
Electrical conductivity, $\mu \mathrm{S} / \mathrm{cm}$ & 6500 \\
Total Dissolved Solids (TDS), mg/l & 3445 \\
Turbidity, NTU & 1077 \\
Total Suspended Solids (TSS), mg/l & 1192 \\
Biochemical Oxygen Demand (BOD), mg/l & 10.3 \\
Chemical Oxygen Demand (COD), mg/l & 15.7 \\
Total Heterotrophic Bacteria (THB), cfu/ml x $10^{3}$ & 1.50 \\
Cyanide ion, mg/l & 4.08 \\
\hline
\end{tabular}

\subsubsection{Isolation of microorganisms}

Microbial colonies were isolated from cassava mill effluent using Nutrient Agar medium (Beef Extract-3 g; Peptone - 5g; Sodium Chloride - 5g; Agar - 20 g; Distilled Water $-1000 \mathrm{ml}, \mathrm{pH}$ 7.0). The bacteria were identified based on colony characteristics, Gram staining and by biochemical tests as given by Bergey's Manual of Determinative Bacteriology and selective media [34].

\subsubsection{Construction of Microbial Fuel Cell (MFC)}

The MFC constructed from plexiglass $(16 \times 16 \times 10 \mathrm{~cm})$ consisted of two chambers for anode and cathode with equal total volume of $1 \mathrm{~L}$ and a working volume of 700 $\mathrm{ml}$. The two chambers are separated by a polyvinyl chloride (PVC) pipe which served as salt bridge (cation exchanger) to transfer protons from anode to cathode chamber. The salt bridge is filled with a mixture of $1 \mathrm{M} \mathrm{KCl}$ and $2 \mathrm{~g}$ agar in $100 \mathrm{ml}$ of distilled water. The salt bridge was fixed between washers and clamped in the hollow tube (50 $\mathrm{mm}$ diameter) attaching both chambers. Carbon rods $(4 \times 5 \mathrm{~cm} ; 10 \mathrm{~mm}$ thickness) coated with nonconductive epoxy was used as electrodes for both anode and cathode.

Prior to use, electrodes were soaked in de-ionized water for a period of $24 \mathrm{~h}$. Anode was perforated by providing nine uniform size holes of $0.1 \mathrm{~cm}$ diameter to increase the surface area. Electrodes were positioned at a distance of $6 \mathrm{~cm}$ on either side of the salt bridge. Copper wire was used as contact for the electrodes after carefully sealing the contact with 'nonconductive epoxy' material. Each chamber was provided with sample port, wire point input (top), inlet and outlet ports and anode chamber was sealed with washers to ensure anaerobic microenvironment.

\subsubsection{Experimental Design}

The cathode chamber of MFC (aerobic chamber where oxygen was used as the electron acceptor for the electrode) was filled with $100 \mathrm{mM}$ phosphate buffer as catholyte mediator and $\mathrm{pH}$ adjusted to 7 by $0.5 \mathrm{M}$ $\mathrm{NaOH}$. Catholyte solution was continuously stirred at $50 \mathrm{rpm}$ using magnetic beads to ensure effective contact between proton, electron and mediator. The cathode chamber was provided with air that passed through a $0.45 \mathrm{~m}$ pore size filter. Under these conditions, the dissolved oxygen (DO) concentrations in the cathode chamber of MFC were observed to be between 4 and $5 \mathrm{mg} / \mathrm{L}$. The anode chamber was initially inoculated with artificial wastewater containing glucose as carbon source. The composition of the artificial wastewater was $1.0 \mathrm{~g}$ glucose, 450.0 $\mathrm{mg} \mathrm{NaHCO}, 100 \mathrm{mg} \mathrm{NH}_{4} \mathrm{Cl} 10.5 \mathrm{mg} \mathrm{K}_{2} \mathrm{HPO}_{4}, 6.0 \mathrm{mg}$

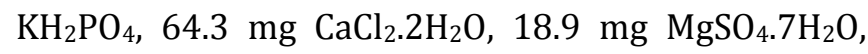
$10.0 \mathrm{mg} \mathrm{FeSO}{ }_{4} .7 \mathrm{H}_{2} \mathrm{O}, 0.65 \mathrm{mg} \mathrm{CuSO}{ }_{4} .5 \mathrm{H}_{2} \mathrm{O}, 6.0 \mathrm{mg}$ $\mathrm{MnSO}_{4}, 0.5 \mathrm{mg} \mathrm{ZnSO}{ }_{4} .7 \mathrm{H}_{2} \mathrm{O}, 20 \mathrm{mg} \mathrm{CoCl} 2.6 \mathrm{H}_{2} \mathrm{O}$ and $0.65 \mathrm{mg} \mathrm{CuSO}_{4} .5 \mathrm{H}_{2} \mathrm{O}\left(\mathrm{gL}^{-1}\right)$.

After two cycles, feed solution containing 50\% artificial wastewater and $50 \%$ cassava liquid waste effluent sample was separately inoculated into the MFC to test-run the MFC. After another two cycles, feed solution was switched to $100 \%$ cassava mill effluent sample. The $\mathrm{pH}$ of the anode was maintained at $6.0( \pm 0.1)$ throughout the experiment to sustain the survival of acidogenic bacteria. The performance of microbial fuel cell was evaluated under ambient temperature $\left(28^{\circ} \mathrm{C} \pm 2{ }^{\circ} \mathrm{C}\right)$ and ambient pressure except during the study of increased temperature effect. The anode chamber was sparged with nitrogen gas for a period of 4 minutes to maintain anaerobic microenvironment after each feeding cycle. Feeding, decanting, and recirculation operations were performed using peristaltic pumps controlled by electronic timer. Fuel Cells were operated for 7 days and readings were taken for 5 days.

\subsubsection{Analytical Procedure}

Current (I) and potential difference (V) measurements were recorded at 30 minutes interval of operation using auto-range digital Multimeter (made by Kusam, model DT-830D) by connecting to 
$100 \Omega$ external circuit. For polarization curve preparation, current generation was monitored at various external resistances (30 $-100 \Omega)$. The readings were recorded after connecting the resistance for few minutes on obtaining stable voltage readings. The current was calculated according to Ohm law, $I=V / R$, where $I(\mathrm{~mA})$ is the current, $V(\mathrm{~V})$ is the voltage, and $R(\Omega)$ is the external resistance. Current density was calculated as $i=I / A$, where $A$ $\left(84 \mathrm{~cm}^{2}\right)$ is the projected surface area of the studied electrode. The power density was calculated according to $P=I V / A$, where $I, V$ and $A$ are the same as previously described.

\section{RESULTS AND DISCUSSION}

\subsection{Bacterial Species Isolated from Effluents}

The microbial species isolated from the cassava mill effluents were found to be Pseudomonas aeruginosa, Bacillus cereus, Bacillus subtilis, Escherichia coli, Saccharomyces cerevisiae, Aspergillus niger, Aspergillus flavus and Rhizopus species.

\subsection{Voltage and Current Generation}

After setting the experiment, the two chambered Mediator Less MFCs were operated with cassava mill effluent sample at different conditions, as feed to support the formation of biomass and subsequent generation of electricity. When MFC was inoculated with cassava mill effluent, there was about $24 \mathrm{~h}$ Lag phase followed by an increase in cell current. The initial increase of current could be attributed to the presence of components that are easily utilized by mixed microorganisms present in the liquid waste. When these easily degradable substrates were exhausted, the current outputs began to decrease.

In this study, a maximum voltage output of $275 \mathrm{mV}$ and a corresponding current output of $2.75 \mathrm{~mA}$ were obtained in $240 \mathrm{~min}(4 \mathrm{~h})$ from the cassava mill effluent as shown in Figure 1.

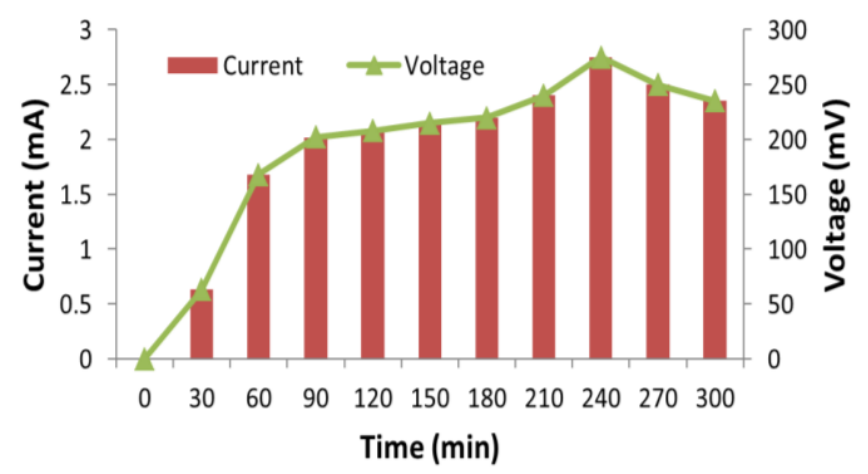

Figure 1: Variation of voltage and current generated from cassava mill effluent with time
Siva et al [35] have reported a maximum current output of $0.957 \mathrm{~mA}$ and $0.851 \mathrm{~mA}$ respectively for dairy and sugar industry wastewaters. Also a maximum current output of $1.28 \mathrm{~mA}, 1.06 \mathrm{~mA}, 0.96$ $\mathrm{mA}, 0.79 \mathrm{~mA}$ and $0.71 \mathrm{~mA}$ obtained in $150 \mathrm{~min}\left(2 \frac{1}{2} \mathrm{~h}\right)$ have been reported by Aremu and Agarry [7] for the use of sugar wastewater, brewery wastewater, abattoir wastewater, pineapple juice wastewater and dairy wastewater as fuel in MFC, respectively. Meanwhile, Mathuriya and Sharma [2] have reported a maximum current output of $8.39 \mathrm{~mA}$ and $11.39 \mathrm{~mA}$ on the $5^{\text {th }}$ day for dairy waste water and sugar industry waste water, respectively in their MFC without mediators. The high current output reported by Mathuriya and Sharma [2] might be due to their use of Nafion 117 Proton exchange membrane, which is reported to be the best PEM in microbial fuel cell experiments as well as higher hydraulic retention time of 10 days. In our case, salt bridge instead of Nafion membrane and a lower hydraulic retention time of $5 \mathrm{~h}$ was used.

Min et al. [28] and Fatemi et al. [36] have reported that Geobactermetallireducens and Saccharomyceses cerevisiae as pure cultures correspondingly produced a power output of $2.2 \mathrm{~mW} / \mathrm{m}^{2}$ and $10 \mathrm{~mW} / \mathrm{m}^{2}$ in their MFC using a salt bridge between anode and cathode chambers while in our study a maximum power density of $189 \mathrm{~mW} / \mathrm{m}^{2}$ (Fig. 1) using a salt bridge was obtained suggesting that a consortium of microorganisms are able to produce more power synergistically than a single pure culture. Similar observations have been reported [2, 36]. These observations also prove the fact that performance of microbial fuel cells with respect to electricity generation is dependent on the availability of various types of microorganisms found in biological waste effluents. Availability of complex mixed cultures allows much wider substrate utilization and thus release of more electrons. This may probably be the reason for higher voltage generation in our MFCs using cassava mill effluents without using any mediators. Some species of Pseudomonas enhance their electron transfer potential through excretion of self-made redox mediator pyocyanin [2,37]. Thus, the presence of Pseudomonas species in our cassava mill effluent may also have influenced the increase in power output through their self-made mediator.

\subsection{Effect of Temperature}

To evaluate the effect of temperature on current generation, the sample was initially operated at $25^{\circ} \mathrm{C}$ 
for $150 \mathrm{~min}\left(2 \frac{1}{2} \mathrm{~h}\right)$ after which the temperature was increased up to $35^{\circ} \mathrm{C}$ for $210 \mathrm{~min}\left(3 \frac{1 / 2}{h}\right)$ and thereafter increased to $45^{\circ} \mathrm{Cfor} 300 \mathrm{~min}(5 \mathrm{~h})$. Figure 2 show the voltage and current generation at the different temperatures.

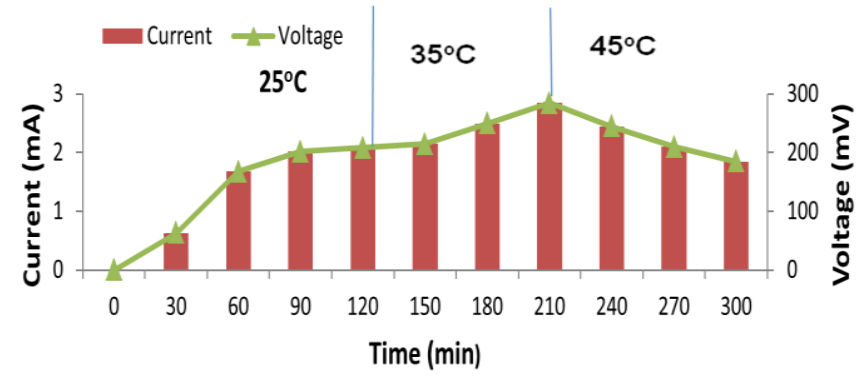

Figure 2: Effect of temperature on voltage and current generation from cassava mill effluent

Experimental data indicate that voltage increased from 202 to $285 \mathrm{mV}$ and the corresponding current generation increased from 2.02 to $2.85 \mathrm{~mA}$ with increase in temperature from 25 to $35^{\circ} \mathrm{C}$. Aremu and Agarry [7] observed an increased current generation from brewery waste water, pineapple juice waste water, abattoir waste water and sugar industry waste water when temperature increased from $25^{\circ} \mathrm{C}$ to $35^{\circ} \mathrm{C}$. However, as the temperature increased from 35 to $45^{\circ} \mathrm{C}$, a major decrease in voltage from 285 to $185 \mathrm{mV}$ and current from 2.85 to $1.85 \mathrm{~mA}$ were observed in the MFC performance. A similar observation has been reported for bioelectricity generation from brewery waste water, paper industry waste water and dairy waste water as temperature was increased from 35 to $45^{\circ} \mathrm{C}[2,38]$.

The result was not unexpected as the ambient temperature for most of the microbial consortium is $30-35^{\circ} \mathrm{C}$. Mansoorian et al. [39] have reported that for the variation of temperature between 15 and $40^{\circ} \mathrm{C}$ in the generation of electricity from dairy waste water, the maximum voltage and current intensity were obtained at $35^{\circ} \mathrm{C}$. Decrease and increase in the voltage efficiency and current intensity may happen due to several reasons. As temperature increases, the rates of biochemical reactions in cells and bacterial growth accelerate and hence the metabolism rate of bacteria increases which leads to quick growth of bacteria and higher voltage efficiency. However, when bacteria are in high temperatures for long duration, important compounds in cells including nucleic acid and other material susceptible to temperature may get damaged irreversibly and this will lead to an intense deterioration of cell function or cell death. In this situation the voltage and current intensity dramatically decreases. Also at low temperatures, rate of bacterial growth is low which leads to decrease in the bacteria population in the anode chamber and operation in these low temperatures is not successful and the voltage efficiency and current intensity becomes low $[40,41,42]$.

\subsection{Effect of Wastewater Concentration}

To evaluate the effect of wastewater concentration on electricity production, the MFC was initially operated at full strength of cassava mill effluent in the anodic chamber for 150 min after which $50 \%$ part of the effluent was replaced by de-ionized water. The effect of cassava mill effluent concentrations on current response is shown in Figure 3.

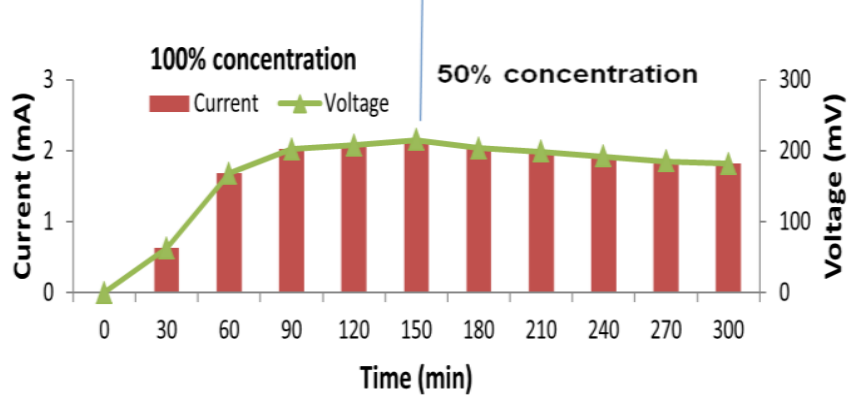

Figure 3: Effect of waste effluent concentration on voltage and current generation from cassava mill effluent

It is seen from Figure 3 that voltage and current generation decreased as cassava mill effluent concentration decreased from $100 \%$ to $50 \%$ concentration (strength). This observation of decreased voltage and current generation may be due to decreased presence of oxidizable substrates in 50\% effluent sample. Similar observations have been reported for municipal waste water, brewery waste water, sugar waste water and paper industry waste water [2].

\subsection{Effect of $\mathrm{pH}$}

The $\mathrm{pH}$ of wastewater entering the anode chamber and the phosphate buffer entering the cathode chamber is one of the parameter that affects current intensity in MFC systems [43]. The anode chamber is anaerobic and microorganisms transfer electrons from the degradation of organic material to the anode electrode. To evaluate the effect of $\mathrm{pH}$ on electricity production, the MFC was initially operated at a $\mathrm{pH}$ of 6.5 in the anodic chamber for $120 \mathrm{~min}$ after which the effluent $\mathrm{pH}$ was adjusted to acidic $\mathrm{pH}$ of 4.5 using $\mathrm{H}_{2} \mathrm{SO}_{4}$ and the system allowed to operate for $210 \mathrm{~min}$ and thereafter adjusted to alkaline $\mathrm{pH}$ of 8 by drop wise addition of $\mathrm{NaOH}$. The effect of effluent $\mathrm{pH}$ on voltage and current response is shown in Figure 4. 
The electrolyte used in this study was phosphate buffer whose $\mathrm{pH}$ was set at 7.0.

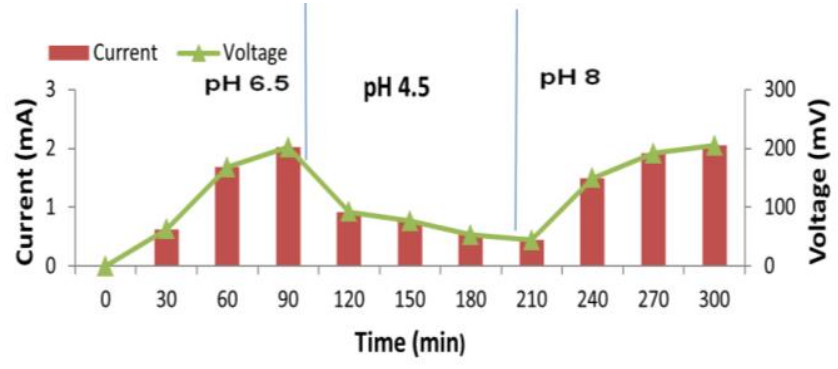

Figure 4: Effect of pH on voltage and current generation from cassava mill effluent

It is seen from Figure 4 that voltage generation continuously increased at $\mathrm{pH}$ of 6.5 from 0 to $202 \mathrm{mV}$ with a corresponding increase in current generation from 0 to $2.02 \mathrm{~mA}$. As the effluent $\mathrm{pH}$ was adjusted to acidic $\mathrm{pH}$ of 4.5, the voltage decreased from $202 \mathrm{mV}$ to $44 \mathrm{mV}$ with a corresponding decrease in current generation from 2.02 to $0.44 \mathrm{~mA}$.

However, with the adjustment of effluent $\mathrm{pH}$ to alkaline $\mathrm{pH}$ of 8, the voltage increased from 44 to 205 $\mathrm{mV}$ while the current intensity increased from 0.44 to $2.05 \mathrm{~mA}$. Similar observations have been reported [44, 45]. This observation of decreased current generation at acidic $\mathrm{pH}$ (i.e. low $\mathrm{pH}$ ) in comparison to alkaline $\mathrm{pH}$ may be due to the fact that at low $\mathrm{pH}$, microorganisms are deactivated and thus microbial activity is reduced which leads to weak transfer of protons to the other side of the salt bridge and ultimately decreases the MFC efficiency. Li et al. [46] and Jadhav et al. [38] have both reported that the maximum efficiency of MFC is attained at $\mathrm{pH}$ 7.0.

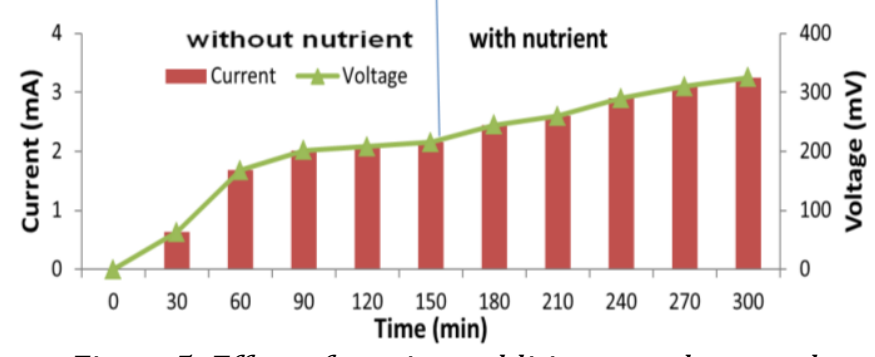

Figure 5: Effect of nutrient addition on voltage and current generation from cassava mill effluent

\subsection{Effect of Nutrient}

To evaluate the effect of nutrient addition (biostimulation) on electricity production, the MFC was initially operated without the addition of NPK fertilizer (nutrient) to cassava mill effluent in the anodic chamber for 150 min after which NPK fertilizer was added. The effect of nutrient addition on voltage and current response is shown in Figure 5.
It is seen from Figure 4 that voltage and current generation continuously increased with the addition of nutrient (NPK fertilizer). This observation of increased voltage and current generation may be due to increased presence of nutrient (nitrogen, potassium and phosphorus) which resulted in increased cell multiplication and growth which subsequently led to increased oxidation of effluent and release of electrons and ultimately higher voltage and current generation.

\section{CONCLUSIONS}

In this study, it can be concluded that electricity can directly be generated from cassava mill effluent using the MFC technology. The maximum current intensity and power density production were achieved respectively at $2.75 \mathrm{~mA}$ and $189 \mathrm{~mW} / \mathrm{m}^{2}$ on the anode surface. The maximum voltage produced was $2.75 \mathrm{mV}$. Also, since the microorganisms responsible for substrate biodegradation for electricity generation were already present in the wastewater; this study proved that MFC function is affected by the operating conditions such as temperature, $\mathrm{pH}$, presence of nutrient, strength (or concentration) of wastewater and retention time. The microbial electricity generation technology is still in the early stage of development in Nigeria; nevertheless, it shows great promise as a new method towards electricity generation from renewable and carbon-neutral sources such as the generation of electricity from negative value streams using the microbial fuel cell technology.

\section{REFERENCES}

[1] Wen, Q, Wu, Y., Cao, D., Zhao, L., and Sun, Q. Electricity generation and modeling of microbial fuel cell from continuous beer brewery wastewater. Bioresource Technology, Vol. 100, 2009, pp 4171- 4175.

[2] Mathuriya, A. S., and Sharma, V. N. Bioelectricity production from various wastewaters through microbial fuel cell technology. Journal of Biochemical Technology, Vol. 2, 2009, pp 133-137.

[3] Davis, F., and Higson, S. P. J. Biofuel cells-recent advances and applications. Biosensor and Bioelectron, Vol. 22, 2007, pp 1224-35.

[4] Moon, H., Chang, I. S., and Kim, B. H. Continuous electricity production from artificial wastewater using a mediator-less microbial fuel cell. Bioresource Technology, Vol. 97, 2006,pp 621627. 
[5] Patil, V. D., Patil, D. B., Deshmukh, M. B., and Pawar, S. H. Comparative study of bioelectricity generation along with the treatment of different sources of wastewater. International Journal of Chemical Sciences and Applications, Vol. 2, 2011, pp 162-168.

[6] Potter, M. C. On the difference of potential due to the vital activity of microorganisms. Proc. Univ Durham Phil Soc, Vol. 3, 1910, pp 245 - 249.

[7] Aremu, M. O. and Agarry, S. E. Bioelectricity potentials of some Nigerian industrial wastewater through microbial fuel cell (MFC) technology. ABHINAV- Journal of Research Science and Technology, Vol. 2,Number 5, 2013, pp 40-48.

[8] Huang, L., Zeng, R. J., and Angelidaki, I. Electricity production from xylose using a mediatorless microbial fuel cell. Bioresource Technology, Vol. 99, 2008, pp 4178-4184.

[9] Mohan, V. S., LalitBabu, V., and Sarma, P. (2008). Effect of various pretreatment methods on anaerobic mixed microflora to enhance biohydrogen production utilizing dairy wastewater as substrate.Bioresource Technology, Vol. 99, 2008, pp 59-67.

[10] Rabaey, K., and Verstraete, W. Microbial fuel cells: Novel biotechnology for energy generation. Trends in Biotechnology, Vol. 23, 2005, pp 291-298.

[11] Bond, D. R., and Lovley, D. R. Electricity production by Geobactersulfurreducens attached to electrodes. Applied and Environmental Microbiology, Vol. 69, Number 3, 2003, pp 15481555.

[12] Rabaey, K., Lissens, G., Siciliano, S. D., and Verstraete, W.A microbial fuel cell capable of converting glucose to electricity at high rate and efficiency. Biotechnology Letters,Vol. 25, 2003, pp 1531-1535.

[13] He, Z., Wagner, N., Minteer, S. D., and Angenent, L. T. An upflow microbial fuel cell with an internal resistance by impedance spectroscopy. Environmental Science and Technology, Vol. 40, 2006, pp 5212-5217.

[14] Logan, B. E., Murano, C., Scott, K., Gray, N. D., and Head, I. M. Electricity generation from cysteine in a microbial fuel cell. Water Research ,Vol. 39, 2005, pp 942-52.

[15] Heilmann, J., and Logan, B. E. Production of electricity from proteins using a single chamber microbial fuel cell. Water Environmental Research, Vol. 78, Number 5, 2006, pp 531-537.

[16] Aelterman, P., Versichele, M., Marzorati, M., Boon, N., and Verstraete, W. Loading rate and external resistance control the electricity generation of microbial fuel cells with different threedimensional anodes. Bioresource Technology, Vol. 99, 2008, pp 8895-8902.
[17] Jae, K. J., The Hai, P., In Seop, C., Kui, H. K., Hyunsoo, M., Kyung, S. C., and Byung, H. K. Construction and operation of a novel mediator- and membrane-less microbial fuel cell. Process Biochemistry, Vol. 38, 2004,pp 1007-1012.

[18] Zhao, F., Harnisch, F., Schro"der U, Scholz, F., Bogdanoff, P., and Herrmann, I. Challenges and constraints of using oxygen cathodes in microbial fuel cells. Environmental Science and Technology, Vol. 40, 2006, pp 5193-5199.

[19] Cheng, S., Liu, H., and Logan, B. E. Increased power generation in a continuous flow MFC with adjective flow through the porous anode and reduced electrode spacing. Environmental Science and Technology, Vol. 40, 2006, pp 2426-2432.

[20] Oh, S. E., Min, B., and Logan, B. E. Cathode performance as a factor in electricity generation in microbial fuel cells. Environmental Science and Technology, Vol. 38, 2004, pp 4900-4904.

[21] Kim, M. S., and Lee, Y. J. Optimization of culture conditions and electricity generation using Geobactersulfurreducens in a dual-chambered microbial fuel-cell. International Journal of Hydrogen Energy, Vol. 35, 2010, pp 13028-13034.

[22] Najafpour, G., Rahimnejad, M. and Ghoreshi, A. The enhancement of a microbial fuel cell for electrical output using mediators and oxidizing agents. Energy Sources, Part A: Recovery, Utilization, and Environmental Effects, Vol. 33,Number 24, 2011,pp 2239-2248.

[23] Park, D., and Zeikus, J. 2000. Electricity generation in microbial fuel cells using neutral red as an electronophore. Appliedand Environmental Microbiology, Vol. 66, 2000, pp 1292.

[24] Du, Z., Li, H., and Gu, T. A state of the art review on microbial fuel cells: a promising technology for wastewater treatment and bioenergy. Biotechnology Advance Vol. 25, 2007, pp. 464482.

[25] He, Z., Shao, H., and Angenent, L. T. Increased power production from a sediment microbial fuel cell with a rotating cathode Biosens. Bioelectron., Vol. 22, 2007, pp. 3252-3255.

[26] Lui, H., Ramnarayanan, R., and Logan, B. E. Production of electricity during wastewater treatment using a single chamber microbial fuel cell. Environmental Science and Technology, Vol. 38, 2004, pp 2281-2285.

[27] Van Ginkel, S., Oh, S. E., and Logan, B. E. Biohydrogen gas production from food processing and domestic wastewaters. International Journal of Hydrogen Energy, Vol. 39, Number 16, 2005, pp 3819-3826.

[28] Min, B., Kim, J. R., and Oh, S. E. Electricity generation from swine wastewater using microbial 
fuel cells'. Water Research, Vol. 39, Number 20, 2005, pp 4961 - 4968.

[29] Zuo, Y., Maness, P. C., and Logan, B. E. Electricity production from steam-exploded corn stover biomass. Energy Fuels,Vol. 20, Number 4, 2006, pp 1716-1721.

[30] Heitner-Wirguin, C. Recent advances in perfluorinated ionomer membranes: Structure, properties and applications. Journal of Membrane Science, Vol. 120, 1996, pp 1-33.

[31] Eric, A. Z. Application of microbial fuel cell technology for a wastewater treatment alternative Biosensor and Bioelectronics, Vol. 15, 2006, pp. 1157-1160.

[32] Chae, K. J., Choi, M., Ajayi, F. F., Park, W., Chang, I. S., and Kim, I. S. Mass transport through a proton exchange membrane (Nafion) in microbial fuel cells. Energy and Fuels, Vol. 22, 2008, pp 169- 176.

[33] APHA, Standard methods for the examination of water and wastewater. American Public Health Association, American Water Works Association and Water EnvironmentFederation,(21sted.), Washington, 2005.

[34] Holt, J. G., Krieg, N. R., Sneath, P. H. A., Stanley, J. T., and William, S. T. 'Bergey's Manual of Determinative Bacteriology'. Baltimore, USA, William and Wilkins, 1994.

[35] Siva, G.V., Prashanthi, R., and Mohan, N. Bioelectricity production from industrial effluents using mediator less microbial fuel cell (MFC). Journal of Environment and Applied Bioresearch, Vol. 2,Number 2, 2014,pp 44-48.

[36] Fatemi, S., Ghoreyshi, A. A., Najafpour, G., and Rahimnejad, M. Bioelectricity Generation in Mediator - less Microbial fuel cell: Application of pure and mixed culture. Iranica Journal of Energy and Environment, Vol. 3, 2012, pp 104-108.

[37] Rabaey, K., Boon, N., Siciliano, S. D., Verhaege, M., and Verstraete, W. Biofuel cells select for microbial consortia that selfmediate electron transfer. Applied and Environmental Microbiology, Vol. 70, 2004, pp 5373-8382.
[38] Jadhav, G.S., and Ghangrekar, M.M. Performance of microbial fuel cell subjected to variation in $\mathrm{pH}$, temperature, external load and substrate concentration Bioresource Technology, Vol. 100, 2009, pp 717-723.

[39] Mansoorian, J. H., Mahvi, A. H., Jafari, A. J., and Khanjani, N. Evaluation of dairy industry wastewater treatment and simultaneous bioelectricity generation in a catalyst-less and mediator-less membrane microbial fuel cell. Journal of Saudi Chemical Society, 2014, In Press.

[40] Min, B., RománÓ, B., and Angelidaki, I. Importance of temperature and anodic medium composition on microbial fuel cell (MFC) performance. Biotechnology Letters, Vol. 30, 2008,pp 12131218.

[41] Kjeang, E., Djilali, N., and Sinton, D. Microfluidic fuel cells: A review. Journal of Power Sources, Vol. 186, 2009,pp 353-369.

[42] Jana, P. S., Behera, M., and Ghangrekar, M.M. Performance comparison of up-flow microbial fuel cells fabricated using proton exchange membrane and earthen cylinder. International Journal of Hydrogen Energy, Vol. 35, 2010, pp 5681-5686.

[43] Behera, M., and Ghangrekar, M. M. Performance of microbial fuel cell in response to change in sludge loading rate at different anodic feed $\mathrm{pH}$. Bioresource Technology, Vol. 100, 2009, pp. 51145121.

[44] Behera, M., Jana, P.S., More, T.T., and Ghangrekar, M.M. Rice mill wastewater treatment in microbial fuel cells fabricated using proton exchange membrane and earthen pot at different pH. Bioelectrochemistry, Vol. 79, 2010, pp 228233.

[45] Puig, S., Serra, M., Coma, M., Cabre, M., DolorsBalaguer, M., andColprim, J. Effect of $\mathrm{pH}$ on nutrient dynamics and electricity production using microbial fuel cells. Bioresource Technology, Vol. 101,Number 24, 2010, pp 9594-9599.

[46] Li, Z., Yao, L., Kong, L., and Liu, H. Electricity generation using a baffled microbial fuel cell convenient for stacking. Bioresource Technology, Vol. 99, 2008, pp 1650-1655. 